\title{
Effect of Levels of Humic Acid at Different Times on Improvement of the Growth of Calendula (Calendula officinalis L.) Plant
}

\author{
Yasser I. El-Nashar
}

\begin{abstract}
Calendula (Calendula officinalis L.) is an annual winter plant that belongs to family Asteraceae. It generally used as landscape bedding or ornamental potted plants. The economic and environmental sustainability of ornamental plants production can be improved by environmentally friendly organic substance, such as humic acid (HA). Seedlings of Calendula were sprayed by the organic foliar (HA) fertilizer $(0.0,0.5,1.0,1.5$, and $2.0 \mathrm{~g} / \mathrm{L})$ for one, two, three and four times every 15 days after transplanting. Growth traits, leaf pigment contents, leaf gas exchange, and leaf water potential of $C$. officinalis were determined. The results showed that plants treated with foliar applications of HA with different levels exhibited plant height, the number of leaves, leaf area, shoot dry mass, and as well as the number of flowers, flowers display time, flower diameter and flower dry mass. The promoting influences of the foliar application of $\mathrm{HA}$ on the growth and development of plants were obvious reflected using the two dose 1.5 and $2.0 \mathrm{~g} / \mathrm{L}$ at three times. Humic acid enhanced vegetative and flowering traits of the Calendula plant, improved leaf pigments content and both photosynthesis rate and transpiration rate. Therefore, HA gives a good chance to improve the growth of Calendula as a model for ornamental plants production.
\end{abstract}

Key words: Calendula, chlorophyll and anthocyanin, gas exchange, leaf water potential, pot marigold, flowering date.

\section{INTRODUCTION}

Calendula (Calendula officinalis L.) is one of the best important plants used in landscape throughout the world. Calendula (pot marigold) is an annual winter plant belongs to family: Asteraceae. Golestani et al. (2013) reported that the common name of Calendula plant is marigold, Scottish marigold, garden marigold, or English marigold. It is refined as borders, rock gardens, balcony plants and as cut flowers. Calendula plant originated from Southern and Eastern Europe, Mediterranean countries and implanted typically in North America and India (Rigane et al., 2013). Calendula plant has orange and yellow flowers rich by carotenoids, essential oils, vitamin A, flavonoids, and other substances (Mohammad and Kashani, 2012). In addition to, it full-grown as an ornamental plant, and has several therapeutic benefits blood refiner, blood sugar diminishing, anti-viral, anti- inflammatory, and skin anti-fungal characters (Mohammad and Kashani, 2012).

Humic acid (HA) is an organic fertilizer derivative from original lignitic coal and is added in a very light concentration (Nisar and Mir, 1989). It is produced from the oxidation/decay of organic substance through microbial action and is naturally establish in lignitic coals, soil, rivers and oceans (Lawson and Stewart, 1989). It is a vital constitutive of soil organic substance and soils empty of HA are problematic to be kept fertile smooth with big applications of chemical fertilizers. Bhardwaj and Gaur (1970) reported that HA assistances as a catalytic agent in serving the activity of microorganisms and diminishes the adverse effects of the chemicals substance on the environment. Because of its aptitude to form multiplexes it can change elements into forms appropriate for assimilation by plant (Vaughan and Donald, 1976). Sibanda and Young (1989) mentioned that the influences of HA on plant and soil are longer-lived from other inorganic sources. Minor level of HA has been reported to enhance moisture, nutrient uptake, plant vegetative growth and root length significantly (Kononova, 1966). Though, higher nutrient contents in the soil have been proclaim to retard the development promoting properties of humic compounds (Sharif et al. 2003). Existence talented natural resource HA can be used as a substitute to artificial mineral fertilizers to increase crop production (Pan and Dong, 1995). Hartwigson and Evans (2000) illustrated that HA is a commercial product contains several elements which improve the soil fertility and cumulative the obtainability of nutrient elements, and thus affect plant vegetative growth and flower yield. De Kreij and Basar (1995) and Mackowiak et al. (2001) reported that HA arrangements are article to increase the uptake of mineral elements to promote the root length; and to increase the fresh and dry weights of vegetative growth for different plants. Arancon et al. (2003) found that HA enhanced the plant growth quality of English name Tagetes patula L., likewise improved quality of vegetative yield and flowers of Gerbera (Gerbera jamesonii L.) cv. 'Malibu' (Nikbakht et al., 2008). Mohammadipour et al. (2012) mentioned that the highest fresh and dry weights of 
flowers were obtained by using of HA on Calendula leaves and flowers number. Foliar application of HA on Chrysanthemum and then, increased the growth and development of plants improve photosynthetic rate owing to the high content of pigments chlorophyll (Fan et al., 2014). Baldotto and Baldotto (2013) reported that using HA at high levels (40 $\mathrm{mmol} \mathrm{L}^{-1}$ ) increased produce and flowering quality of Gladiolus.

In view of the facts specified above, the study was conducted to evaluate the effect of different levels of HA and application times on vegetative and flowering growth, and yield of Calendula as a model and important annual winter ornamental potted plants.

\section{MATERIALS AND METHODS}

\section{Plant material and experimental conditions}

This study was performed at the experimentation station of the College of Food and Agriculture Sciences, Plant Production Dept., King Saud University, Saudi Arabia, (24 44' $12.66^{\circ} " \mathrm{~N}$ and $46^{\circ} 37^{\prime} 13.32^{\prime \prime} \mathrm{E}$, Elevation: $600 \mathrm{~m}$ ) during the two successive growing seasons (from September to April), of 2017/2018 and 2018/2019 on Calendula (Calendula officinalis L.) plants. A climatic condition of Riyadh area is generally desert and receives very slight precipitation through the growth season. Annual precipitation rate in Riyadh province is $100 \mathrm{~mm}$ of rain fall, nearly all occurring from November to April, and will be of 120/125 mm per month in March and April and though, relative humidity is very low. The soil of the investigational field was clay loamy with $\mathrm{pH} 7.8$, consisted of clay $(8.9 \%)$, sand $(81.2 \%)$ and silt $(9.9 \%)$; contains total K (118 ppm), total $\mathrm{N}$ (192 ppm), and total $\mathrm{P}$ (9.1 ppm) with an EC of $0.14 \mathrm{ds} \mathrm{m}^{-1}$ (average two years).

Calendula seeds were planted in $50 \times 60 \mathrm{~cm}^{2}$ plastic trays full with a combination of sand and peat moss medium $(1: 1 ; \mathrm{v}: \mathrm{v})$ for germination and watered daily until four to five true leaves had appeared at almost one month later. At this phase, plants with the same heights were chosen from the nursery and transplanted into 20 $\mathrm{cm}$ width plastic pots (one seedling/pot). Calendula seeds were planted in nursery in 25 September and transplanted in the field on 26 October of both study years. After transplanting, the plants were carefully irrigated three times with fresh water to keep soil moisture near to the field capacity $(80 \%$, v/w). One week after transplanting, the foliar HA treatments were started. Humic acid (Humic acid 86\% + 6\%, Huma K, Humic acid $56 \%$, fulvic acid $30 \%$, potassium $6 \%$ min, solubility $98 \%$ minimum on water, Al jammaz group, Saudi Arabia) foliar treatment were applied as follows: one time in the first spray (T1) (7 days after transplanting), two times in both first and second sprays (T2) (7 and 21 days after transplanting), three times in all first, second and third sprays (T3) (7, 22 and 37 days after transplanting), and four times in all first, second, third and fourth sprays (T4) (7, 22, 37 and 52 days after transplanting) with five concentrations $(0,0.5,1.0,1.5$ and $2.0 \mathrm{~g} / \mathrm{l}$ ). At the end of experiment in growth stage, three random plants per replicate were selected to determine and measure the vegetative and flowering growth traits.

\section{Plant measurements}

Data collection included recording vegetative and flowering characters such as plant height $(\mathrm{cm})$, number of branches and leaves, leaf area $\left[\mathrm{cm}^{2}\right]$ recorded using LI-COR portable area meter model 3000A (Germany), shoot dry mass $(\mathrm{g})$, flowering date (days), number of flowers, diameter of flower $(\mathrm{cm})$, flowers dry mass plant $^{-1}(\mathrm{~g})$ and root length $(\mathrm{cm})$. Dry mass was dried at $70^{\circ} \mathrm{C}$ for $48 \mathrm{~h}$. until reaching a constant weight using an Oven Scientific Series 2000 (Laval, Quebec, Canada).

\section{Leaf pigments contents}

Relative leaf total chlorophyll and anthocyanin contents were measured using CCM-200 plus and ACM-200 plus portable chlorophyll and anthocyanin apparatus, respectively (Opti-Sciences, Inc. Hudson, NH, U.S.A.).

\section{Gas exchange measurements}

Gas exchange determinations were conducted in fully expanded sixth leaves by a Li-COR 6400 portable photosynthesis system (LI-COR Inc., Lincoln, U.S.A.). The transpiration rate $(E)$, intercellular $\mathrm{CO}_{2}$ concentration $\left(C_{i}\right)$, stomatal conductance $\mathrm{H}_{2} \mathrm{O}\left(g_{s}\right)$, and the net photosynthetic rate $\left(P_{n}\right)$ parameters was measurement among 11:10 and 12:25 am under a sunlit day with a photosynthetic photon flux density (PPFD) of radiation $1150 \mu \mathrm{mol} \quad \mathrm{m}^{-2} \mathrm{~s}^{-1}$, ambient area temperature of $32^{\circ} \mathrm{C}$, relative humidity $57 \%$, and with the reference $\mathrm{CO}_{2}$ concentration of the respective growth chamber.

\section{Leaf water potential}

The leaf water potential $\left(\Psi_{\mathrm{WP}}\right)$ was measured on leaves at anthesis by means of the water potential system model PSYPRO portable integrating a pressure chamber (Wescor Inc., Utah., USA). Determines were continuously achieved at approximately 10:10 am, the time of day at which sunny strength was utmost, and thus when the Calendula plant water content and leaf water potential $\left(\Psi_{\mathrm{WP}}\right)$ were at their minimum and maximum values.

\section{Experimental design and statistical analyses}

The data were subjected to analysis of variance (ANOVA) using Statistical Analysis System program (SAS 9.2). In a randomized complete block design (R.C.B.D.) with three replications, the experimental treatments were organized in a split plot system, 
following the process outlined by Steel et al. (1997). Analyses were performed by the Statistical Analysis System [SAS/ASSIST, 9.2] software program (SAS Institute, Cary, NC, U.S.A.). The means of treatments were compared using least significant difference (L.S.D.) at $P \leq 0.05$. The four times foliar treatments of HA (one time, two times, three times and four times sprayed on plants) were arranged in the main plots, and the five concentrations of HA treatment (control, 0.5, $1.0,1.5$ and $2.0 \mathrm{~g} / \mathrm{L}$ ) were randomly billed to the subplots. Each plot included three potted Calendula plants in each replicate. In overall, the responses of 180 plants (four times foliar application of HA $\times$ five concentrations of HA treatment $x$ three replicates $\times$ three plants per replicate) were evaluated.

\section{RESULTS AND DISCUSSIONS}

\section{RESULTS}

The analyses of variance for the data of the studied characters reflected significant or highly significant values for both main effect and the interaction effect in all studied characters. Therefore, the results of the interaction between the two factors were presented and discussed, and the effect of the main factor was not presented, as the effect of the interaction was significant.

\section{Vegetative growth parameters}

Data in Table (1) showed the interaction between foliar application times of HA and the levels of HA treatment sprayed on vegetative growth and flowering parameters of Calendula plants through the two successive growing seasons.

The data indicated that foliar treatments of HA and their concentrations significantly affected plant height, number of branches, number of leaves, leaf area and shoot dry mass plant ${ }^{-1}$, these parameters were achieved under $2.0 \mathrm{~g} / \mathrm{L}$ foliar application of HA at three times application and the lowest vegetative parameters were obtained under control conditions.

Table 1. Vegetative growth parameters of Calendula officinalis L. plants as affected by humic acid levels and foliar applications time during the first- and second- seasons (2017/18 and 2018/19), respectively

\begin{tabular}{|c|c|c|c|c|c|c|c|c|c|c|c|}
\hline \multirow{2}{*}{$\begin{array}{c}\text { Add } \\
\text { times }\end{array}$} & \multirow{2}{*}{ Levels } & \multicolumn{2}{|c|}{$\begin{array}{c}\text { Plant height } \\
(\mathbf{c m})\end{array}$} & \multicolumn{2}{|c|}{$\begin{array}{c}\text { Number of } \\
\text { branches plant }^{-1}\end{array}$} & \multicolumn{2}{|c|}{$\begin{array}{c}\text { Number of } \\
\text { leaves plant }{ }^{-1}\end{array}$} & \multicolumn{2}{|c|}{$\begin{array}{c}\text { Leaf area } \\
\text { plant }^{-1}\left(\mathrm{~cm}^{2}\right)\end{array}$} & \multicolumn{2}{|c|}{$\begin{array}{l}\text { Shoot dry mass } \\
\text { plant }^{-1}(\mathrm{~g})\end{array}$} \\
\hline & & $\mathbf{1}^{\text {st }}$ season & $2^{\text {nd }}$ season & $\begin{array}{c}1^{\text {st }} \\
\text { season }\end{array}$ & $2^{\text {nd }}$ season & $1^{\text {st }}$ season & $\begin{array}{c}\text { 2nd } \\
\text { season }\end{array}$ & & $2^{\text {nd }}$ season & $\begin{array}{c}1^{\text {st }} \\
\text { season }\end{array}$ & $\begin{array}{c}2^{\text {nd }} \\
\text { season }\end{array}$ \\
\hline \multirow{5}{*}{1} & Cont. & $17.43 \mathrm{~d}$ & $17.73 \mathrm{ij}$ & $1.70 \mathrm{~d}$ & $2.36 \mathrm{i}$ & $19.68 \mathrm{efg}$ & $25.06 \mathrm{gh}$ & $70.08 \mathrm{bcd}$ & 73.05hi & $2.84 \mathrm{e}$ & $3.86 \mathrm{bc}$ \\
\hline & $0.5 \mathrm{~g} / \mathrm{L}$ & $18.93 \mathrm{~cd}$ & 19.93ghi & $2.70 \mathrm{bcd}$ & 4.06efg & $20.66 \mathrm{efg}$ & $27.43 \mathrm{efg}$ & $79.44 \mathrm{bcd}$ & 73.48hi & $3.18 \mathrm{cde}$ & $3.91 b c$ \\
\hline & $1.0 \mathrm{~g} / \mathrm{L}$ & $21.03 \mathrm{bcd}$ & $22.73 \mathrm{def}$ & $3.07 \mathrm{a}-\mathrm{d}$ & 4.40def & $20.33 \mathrm{efg}$ & $27.70 \mathrm{efg}$ & $89.02 \mathrm{abc}$ & $90.37 \mathrm{ef}$ & $3.21 \mathrm{cde}$ & $3.97 b c$ \\
\hline & $1.5 \mathrm{~g} / \mathrm{L}$ & $22.83 a-d$ & 24.16b-e & $2.43 \mathrm{bcd}$ & $4.76 \mathrm{cde}$ & $22.67 \mathrm{~d}-\mathrm{g}$ & 29.36efg & 92.71abc & 94.92de & $3.66 b c$ & $4.39 \mathrm{ab}$ \\
\hline & $2.0 \mathrm{~g} / \mathrm{L}$ & $23.38 \mathrm{abc}$ & 23.90cde & $2.80 \mathrm{bcd}$ & $5.76 b c$ & $28.35 \mathrm{bcd}$ & 33.33de & 103.30ab & 95.33de & $3.69 b c$ & $3.71 b c$ \\
\hline \multirow{5}{*}{2} & Cont. & $16.27 \mathrm{e}$ & $15.46 \mathrm{j}$ & $2.07 \mathrm{~cd}$ & $2.73 \mathrm{hi}$ & $18.03 \mathrm{fg}$ & $24.06 \mathrm{gh}$ & $59.90 \mathrm{~cd}$ & $68.74 \mathrm{i}$ & $2.98 \mathrm{de}$ & $3.46 b c$ \\
\hline & $0.5 \mathrm{~g} / \mathrm{L}$ & $20.50 \mathrm{bcd}$ & 20.00ghi & $2.41 \mathrm{bcd}$ & $3.66 \mathrm{e}-\mathrm{h}$ & $19.02 \mathrm{efg}$ & $19.40 \mathrm{~h}$ & $82.94 \mathrm{bcd}$ & $95.93 \mathrm{de}$ & $3.61 \mathrm{bcd}$ & $3.87 b c$ \\
\hline & $1.0 \mathrm{~g} / \mathrm{L}$ & $19.43 \mathrm{bcd}$ & $21.03 \mathrm{fgh}$ & $2.50 \mathrm{bcd}$ & $3.83 \mathrm{e}-\mathrm{h}$ & $19.33 \mathrm{efg}$ & $28.43 \mathrm{efg}$ & $80.17 \mathrm{bcd}$ & $85.40 \mathrm{efg}$ & $3.15 \mathrm{cde}$ & $3.82 \mathrm{bc}$ \\
\hline & $1.5 \mathrm{~g} / \mathrm{L}$ & $22.07 \mathrm{bcd}$ & $22.46 \mathrm{efg}$ & $3.37 \mathrm{abc}$ & $5.46 \mathrm{bcd}$ & $30.33 b c$ & $39.43 \mathrm{abc}$ & $93.34 \mathrm{abc}$ & $104.53 \mathrm{bcd}$ & $3.58 \mathrm{bcd}$ & $4.12 \mathrm{abc}$ \\
\hline & $2.0 \mathrm{~g} / \mathrm{L}$ & $21.37 \mathrm{bcd}$ & $25.36 \mathrm{bcd}$ & $3.73 a b$ & $5.43 \mathrm{bcd}$ & $31.02 \mathrm{ab}$ & $43.40 \mathrm{ab}$ & $90.37 \mathrm{abc}$ & 110 & $3.78 \mathrm{bc}$ & $4.29 \mathrm{abc}$ \\
\hline \multirow{5}{*}{3} & Cont. & $21.00 \mathrm{bcd}$ & 19.23hi & $2.13 \mathrm{~cd}$ & $2.40 \mathrm{i}$ & $16.67 \mathrm{~g}$ & $25.03 \mathrm{gh}$ & $52.87 \mathrm{~d}$ & 73.67hi & 2.96de & $3.63 b c$ \\
\hline & $0.5 \mathrm{~g} / \mathrm{L}$ & $21.60 \mathrm{bcd}$ & $18.10 \mathrm{i}$ & $2.42 \mathrm{bcd}$ & $3.03 \mathrm{ghi}$ & 20.66efg & $25.73 \mathrm{fg}$ & $67.38 \mathrm{bcd}$ & 76.17ghi & $3.38 \mathrm{~b}-\mathrm{e}$ & $3.10 \mathrm{c}$ \\
\hline & $1.0 \mathrm{~g} / \mathrm{L}$ & $24.70 \mathrm{ab}$ & 19.40hi & $3.03 \mathrm{a}-\mathrm{d}$ & 4.40def & $24.35 c-f$ & $31.43 \mathrm{ef}$ & $77.77 \mathrm{bcd}$ & 86.42ef & $3.78 b c$ & $3.88 b c$ \\
\hline & $1.5 \mathrm{~g} / \mathrm{L}$ & $22.17 \mathrm{bcd}$ & $22.53 \mathrm{efg}$ & $3.40 \mathrm{abc}$ & $6.06 \mathrm{ab}$ & $22.17 \mathrm{~d}-\mathrm{g}$ & $33.00 \mathrm{de}$ & $65.89 \mathrm{bcd}$ & 113.26ab & $3.92 b$ & $4.45 \mathrm{ab}$ \\
\hline & $2.0 \mathrm{~g} / \mathrm{L}$ & $28.26 \mathrm{a}$ & $36.73 a$ & $4.43 \mathrm{a}$ & $7.06 \mathrm{a}$ & $38.02 \mathrm{a}$ & $44.40 \mathrm{a}$ & $121.59 \mathrm{a}$ & $118.45 \mathrm{a}$ & $4.92 \mathrm{a}$ & $5.14 \mathrm{a}$ \\
\hline \multirow{5}{*}{4} & Cont. & $18.41 \mathrm{~cd}$ & $17.63 \mathrm{ij}$ & $1.71 \mathrm{~d}$ & $3.33 \mathrm{f}-\mathrm{i}$ & 19.30efg & 28.70efg & $55.61 \mathrm{~cd}$ & 75.08hi & $3.16 \mathrm{cde}$ & $3.55 b c$ \\
\hline & $0.5 \mathrm{~g} / \mathrm{L}$ & $19.93 \mathrm{bcd}$ & $26.70 \mathrm{~b}$ & $3.37 \mathrm{abc}$ & 3.66 & $25.68 \mathrm{cde}$ & $37.40 \mathrm{~cd}$ & $61.53 \mathrm{~cd}$ & $83.06 \mathrm{fgh}$ & $3.39 \mathrm{~b}-\mathrm{e}$ & $3.97 b c$ \\
\hline & $1.0 \mathrm{~g} / \mathrm{L}$ & $21.37 \mathrm{bcd}$ & $24.76 b-e$ & $3.73 \mathrm{ab}$ & $5.40 \mathrm{bcd}$ & $21.67 \mathrm{~d}-\mathrm{g}$ & $38.33 \mathrm{bcd}$ & 1 84.26a-d & $87.81 \mathrm{ef}$ & $3.64 b c$ & $3.96 b c$ \\
\hline & $1.5 \mathrm{~g} / \mathrm{L}$ & $21.81 \mathrm{bcd}$ & $25.90 b c$ & $4.37 \mathrm{a}$ & $4.70 \mathrm{cde}$ & $35.03 \mathrm{ab}$ & 33.13de & $88.65 \mathrm{abc}$ & $102.82 \mathrm{~cd}$ & $3.69 b c$ & $4.14 \mathrm{abc}$ \\
\hline & $2.0 \mathrm{~g} / \mathrm{L}$ & $22.31 \mathrm{bcd}$ & 24.66b-e & $3.77 \mathrm{ab}$ & $3.36 \mathrm{f}-\mathrm{i}$ & $22.34 \mathrm{~d}-\mathrm{g}$ & $30.13 \mathrm{efg}$ & $101.85 \mathrm{ab}$ & $111.62 \mathrm{abc}$ & $4.91 \mathrm{a}$ & $4.41 \mathrm{ab}$ \\
\hline
\end{tabular}

*Values in each column followed by different superscript letter(s) are significantly different at $P \leq 0.05$. 
The influence of HA treatments under different addition times on the plant height trait was statistically significant increase in comparison with untreated control in both seasons. The lowest value for average plant height was produced under HA for three times at $2.0 \mathrm{~g} / \mathrm{L}$ foliar application $(28.26$ and $36.73 \mathrm{~cm}$ for the first and second seasons, respectively). The minimum plant height was detected under unsprayed HA plants (16.27 and $15.46 \mathrm{~cm}$ in the two seasons, respectively). Treating Calendula plants by the high level of HA (2.0 $\mathrm{g} / \mathrm{L})$ for three times produced the tallest plants which reached $34.57 \%$ and $91.00 \%$ over the control plants in the two seasons, respectively.

The mean values for the spray times of HA treatments and foliar application concentrations had significant effects on branch number in the two seasons (Table 1). The greatest number of branches plant ${ }^{-1}$ was noticed at $2.0 \mathrm{~g} / \mathrm{L}$ for three times of HA (4.43 and 7.06 in both seasons, respectively), while the smallest number was recorded for the HA control (1.70 and 2.36 in both seasons, respectively).

Significant differences were noticed amongst Calendula plant in the number of leaves plant ${ }^{-1}$. At lower HA concentration $(0.5 \mathrm{~g} / \mathrm{L})$ an increase in number of leaves plant ${ }^{-1}$ was detected with increasing adding times. The highest leaf number (38.02 and 44.40) was observed at $2.0 \mathrm{~g} / \mathrm{L}$ with three foliar application times. But, at the control treatment with all HA treatments, a reduction in leaf number plant ${ }^{-1}$ was detected (Table 1).

The results displayed in Table (1) showed clear differences in leaf area trait below the studied HA foliar treatments. The higher HA concentration $2.0 \mathrm{~g} / \mathrm{L}$, combined with a three times of foliar application, resulted in the largest leaf areas (121.59 and 118.45 $\mathrm{cm}^{2}$ ) for the both seasons, respectively. On the other hand, the unsprayed foliar application caused the smallest leaf area of plants.

The interaction mean values of the HA treatments (times and levels of HA foliar application) reflected significant differences in plant shoot dry mass during the two seasons. The effects of the highest foliar application of HA $(2.0 \mathrm{~g} / \mathrm{L})$ under three spray times increased significantly the plant shoot dry mass (4.92 and $5.14 \mathrm{~g}$ ) through both seasons respectively. In contrast, at the control treatment, shoot dry mass plant ${ }^{-1}$ increased with all increasing addition times as compared with the unsprayed plants (Table 1).

\section{Flowering growth parameters \\ Flowering date}

Humic acid positively affected the flowering parameters of Calendula plants. Data presented in Table (2) indicated that flowering date was significantly affected by using HA in the both seasons. It was clear that the control Calendula plants level contributed the delay flowering date in comparison with sprayed plants by HA in both seasons. The earliest flowering dates were noticed at HA $(2.0 \mathrm{~g} / \mathrm{L})$ with three foliar treatment times (150.30 days) for the first- and (171.06 days) second-seasons, however the latest date was achieved at control Calendula plants (189.32 and 201.43 days in both seasons, respectively) with two times of foliar treatment.

The data in Table (2) displayed that the highest level of HA significantly augmented number of flowers plant ${ }^{-}$ ${ }^{1}$ compared to unsprayed plants in the both seasons. In the meantime, the $1.5 \mathrm{~g} / \mathrm{L}$ level of HA with three foliar application time's significantly increased flowers number in comparison with unsprayed treatment in the two seasons. Treatment $1.5 \mathrm{~g} / \mathrm{L}$ of HA with three application time's produced the highest number of flowers which increased to 5.73 and 5.06 in comparison with the control in both seasons, respectively.

In the both seasons, the highest mean diameter of flower was detected at the $1.5 \mathrm{~g} / \mathrm{L}$ level of HA with three application time's $(5.93$ and $6.33 \mathrm{~cm})$, while the lowest flower diameter was noticed at the control plants with one application time's $(4.13$ and $3.53 \mathrm{~cm})$ in both seasons, respectively.

For flowers dry mass plant ${ }^{-1}$ trait, HA levels significantly augmented flowers dry mass plant $^{-1}$ comparing to unsprayed plants in both seasons. The heaviest flowers dry mass was attained when providing the plants with the highest level $2.0 \mathrm{~g} / \mathrm{L}$ of HA with three application time's which increased it to 3.30 and $3.97 \mathrm{~g}$, while the lightest flowers dry mass were obtained by the unsprayed plants with one application time's $(0.89$ and $1.47 \mathrm{~g})$ in the first and the second seasons, respectively.

The highest HA level $(2.0 \mathrm{~g} / \mathrm{L})$ combined with three sprayed application times resulted in an increase in root length (34.25 and $26.20 \mathrm{~cm})$ in both seasons, respectively. On the other hand, negative effects on root length at the unsprayed Calendula plants with three application time's $(20.32$ and $12.10 \mathrm{~cm})$ were also observed in the both seasons (Table 2). 
Table 2. Flowering parameters of Calendula officinalis L. plants as affected by humic acid levels and foliar applications time during the first- and second- seasons (2017/18 and 2018/19), respectively

\begin{tabular}{|c|c|c|c|c|c|c|c|c|c|c|c|}
\hline \multirow{2}{*}{$\begin{array}{l}\text { Add } \\
\text { times }\end{array}$} & \multirow{2}{*}{ Levels } & \multicolumn{2}{|c|}{$\begin{array}{l}\text { Flowering date } \\
\text { (days) }\end{array}$} & \multicolumn{2}{|c|}{$\begin{array}{c}\text { Number of } \\
\text { flowers plant }^{-1}\end{array}$} & \multicolumn{2}{|c|}{$\begin{array}{l}\text { Diameter of } \\
\text { flower }(\mathbf{c m})\end{array}$} & \multicolumn{2}{|c|}{$\begin{array}{l}\text { Flower dry } \\
\text { mass } \\
\text { plant }^{-1}(\mathrm{~g})\end{array}$} & \multicolumn{2}{|c|}{$\begin{array}{l}\text { Root length } \\
(\mathrm{cm})\end{array}$} \\
\hline & & $1^{\text {st }}$ season & & $\begin{array}{c}1^{\text {st }} \\
\text { season }\end{array}$ & $\begin{array}{c}2^{\text {nd }} \\
\text { season }\end{array}$ & $1^{\text {st }}$ season & $\begin{array}{c}2^{\text {nd }} \\
\text { season }\end{array}$ & $1^{\text {st }}$ season & $\begin{array}{c}2^{\text {nd }} \\
\text { season }\end{array}$ & $1^{\text {st }}$ season & $\begin{array}{c}2^{\text {nd }} \\
\text { season }\end{array}$ \\
\hline \multirow{5}{*}{1} & Cont. & $189.02 \mathrm{ab}$ & 197.10abc & $2.13 \mathrm{~g}$ & $1.73 \mathrm{gh}$ & $4.13 \mathrm{gh}$ & $3.53 \mathrm{f}$ & $0.89 \mathrm{~d}$ & $1.47 \mathrm{~d}$ & $24.57 \mathrm{~b}-\mathrm{e}$ & $13.30 \mathrm{k}$ \\
\hline & $0.5 \mathrm{~g} / \mathrm{L}$ & $183.00 \mathrm{a}-\mathrm{d}$ & & $3.43 \mathrm{cde}$ & & $4.30 \mathrm{gh}$ & $4.56 \mathrm{de}$ & $1.41 \mathrm{~cd}$ & $1.71 \mathrm{~cd}$ & 26.33a-e & $17.03 \mathrm{~g}-\mathrm{j}$ \\
\hline & $1.0 \mathrm{~g} / \mathrm{L}$ & $174.00 \mathrm{~d}-\mathrm{g}$ & $182.33 \mathrm{~d}-\mathrm{g}$ & $3.73 \mathrm{bcd}$ & & $4.83 c-g$ & $4.90 \mathrm{~b}-\mathrm{e}$ & $2.08 \mathrm{a}-\mathrm{d}$ & $1.61 \mathrm{~cd}$ & 28.20a-e & 17.96fgh \\
\hline & $1.5 \mathrm{~g} / \mathrm{L}$ & $190.01 \mathrm{a}$ & & $3.37 \mathrm{c}-\mathrm{f}$ & $3.06 \mathrm{de}$ & $4.37 \mathrm{fgh}$ & $5.26 \mathrm{bcd}$ & $1.31 \mathrm{~cd}$ & $1.76 \mathrm{~cd}$ & 29.26a-d & $22.56 \mathrm{bcd}$ \\
\hline & $2.0 \mathrm{~g} / \mathrm{L}$ & 169.6 & & $3.50 \mathrm{~b}$ & & & & $2.25 \mathrm{a}-\mathrm{d}$ & $1.49 \mathrm{~d}$ & & cde \\
\hline \multirow{5}{*}{2} & Cont. & $189.32 \mathrm{a}$ & $201.43 \mathrm{a}$ & 2.36efg & $46 \mathrm{~h}$ & gh & $4.53 \mathrm{de}$ & $1.51 \mathrm{~cd}$ & $1.60 \mathrm{~cd}$ & $24.07 \mathrm{~b}-\mathrm{e}$ & $13.76 \mathrm{jk}$ \\
\hline & $0.5 \mathrm{~g} / \mathrm{L}$ & $177.31 \mathrm{c}-\mathrm{f}$ & 199.80ab & $3.40 \mathrm{cde}$ & 2.40efg & & & $2.31 \mathrm{a}-\mathrm{d}$ & $1.70 \mathrm{~cd}$ & $27.40 \mathrm{a}-\mathrm{e}$ & $50 \mathrm{~d}-\mathrm{g}$ \\
\hline & $1.0 \mathrm{~g} / \mathrm{L}$ & $187.67 \mathrm{abc}$ & $196.70 \mathrm{abc}$ & $3.80 \mathrm{bcd}$ & 2.76def & $4.80 \mathrm{c}-\mathrm{h}$ & $5.60 \mathrm{abc}$ & $1.35 \mathrm{~cd}$ & $1.85 \mathrm{~cd}$ & $22.15 \mathrm{cde}$ & 17.13ghi \\
\hline & $1.5 \mathrm{~g} / \mathrm{L}$ & 178 & & $3.73 \mathrm{~b}$ & & $5.43 \mathrm{a}-\mathrm{d}$ & $\mathrm{cd}$ & $3.21 \mathrm{ab}$ & $2.24 \mathrm{~cd}$ & $7 \mathrm{ab}$ & $20.40 \mathrm{~d}-\mathrm{g}$ \\
\hline & $2.0 \mathrm{~g} / \mathrm{L}$ & & & $4.02 \mathrm{bc}$ & & & & $3.23 \mathrm{a}$ & $1.49 \mathrm{~d}$ & $32.20 \mathrm{ab}$ & $24.20 \mathrm{abc}$ \\
\hline \multirow{5}{*}{3} & Cont. & 186.0 & $194.66 a-d$ & $2.17 \mathrm{fg}$ & $2.06 f g$ & $4.10 \mathrm{~h}$ & $4.73 \mathrm{cde}$ & $1.72 \mathrm{bcd}$ & $1.53 \mathrm{~d}$ & $20.32 \mathrm{e}$ & $12.10 \mathrm{k}$ \\
\hline & $0.5 \mathrm{~g} / \mathrm{L}$ & $171.00 \mathrm{e}-\mathrm{h}$ & $190.73 a-e$ & $2.73 \mathrm{~d}-\mathrm{g}$ & & $4.76 \mathrm{~d}-\mathrm{h}$ & & $2.64 \mathrm{abc}$ & $1.55 \mathrm{~d}$ & $21.40 \mathrm{de}$ & $18.13 \mathrm{e}-\mathrm{h}$ \\
\hline & $1.0 \mathrm{~g} / \mathrm{L}$ & $174.33 \mathrm{def}$ & $194.33 \mathrm{a}-\mathrm{d}$ & $3.83 \mathrm{bcd}$ & $2.45 \mathrm{efg}$ & $4.63 \mathrm{e}-\mathrm{h}$ & $5.13 \mathrm{bcd}$ & $2.14 \mathrm{a}-\mathrm{d}$ & $2.12 \mathrm{~cd}$ & 26.93a-e & 14.26ijk \\
\hline & $1.5 \mathrm{~g} / \mathrm{L}$ & $161.35 \mathrm{~h}$ & $172.00 \mathrm{fg}$ & $5.73 \mathrm{a}$ & $5.06 \mathrm{a}$ & $5.93 \mathrm{a}$ & & $3.14 \mathrm{ab}$ & $2.16 \mathrm{~cd}$ & 28.26a-e & $25.06 a b$ \\
\hline & $2.0 \mathrm{~g} / \mathrm{L}$ & $150.30 \mathrm{i}$ & $171.06 \mathrm{~g}$ & $4.70 \mathrm{ab}$ & $4.06 b c$ & $5.17 \mathrm{~b}-\mathrm{e}$ & $5.26 \mathrm{bcd}$ & $3.30 \mathrm{a}$ & $3.97 \mathrm{a}$ & $34.25 \mathrm{a}$ & $26.20 \mathrm{a}$ \\
\hline \multirow{5}{*}{4} & Cont. & $180.33 \mathrm{a}-\mathrm{e}$ & $196.70 \mathrm{abc}$ & 2.36efg & $1.76 \mathrm{gh}$ & $4.20 \mathrm{gh}$ & $4.13 \mathrm{ef}$ & $1.31 \mathrm{~cd}$ & $1.60 \mathrm{~cd}$ & $23.13 \mathrm{cde}$ & $15.06 \mathrm{~h}-\mathrm{k}$ \\
\hline & $0.5 \mathrm{~g} / \mathrm{L}$ & $177.67 \mathrm{c}-\mathrm{f}$ & $184.66 \mathrm{c}-\mathrm{f}$ & $2.80 \mathrm{~d}-\mathrm{g}$ & 2.70def & $4.77 \mathrm{~d}-\mathrm{h}$ & $5.66 \mathrm{ab}$ & $1.97 \mathrm{a}-\mathrm{d}$ & $2.62 b c$ & 25.06b-e & $17.00 \mathrm{~g}-\mathrm{j}$ \\
\hline & $1.0 \mathrm{~g} / \mathrm{L}$ & $161.68 \mathrm{~h}$ & $183.33 \mathrm{c}-\mathrm{g}$ & $3.40 \mathrm{cde}$ & $4.76 \mathrm{ab}$ & $4.50 \mathrm{e}-\mathrm{h}$ & $5.06 \mathrm{bcd}$ & $1.84 \mathrm{a}-\mathrm{d}$ & $3.18 \mathrm{ab}$ & $25.20 \mathrm{~b}-\mathrm{e}$ & 17.66fgh \\
\hline & $1.5 \mathrm{~g} / \mathrm{L}$ & & & $5.67 \mathrm{a}$ & & & & $1.25 \mathrm{~cd}$ & $3.48 \mathrm{ab}$ & $29.53 \mathrm{a}-\mathrm{d}$ & 20.96def \\
\hline & $2.0 \mathrm{~g} / \mathrm{L}$ & $163.66 \mathrm{gh}$ & $180.00 \mathrm{efg}$ & $3.33 \mathrm{c}-\mathrm{g}$ & $1.43 \mathrm{~h}$ & $5.50 \mathrm{abc}$ & $5.56 a b c$ & $1.82 \mathrm{a}-\mathrm{d}$ & $1.99 \mathrm{~cd}$ & $32.27 \mathrm{ab}$ & $25.90 \mathrm{a}$ \\
\hline
\end{tabular}

*Values in each column followed by different superscript letter(s) are significantly different at $\mathrm{P} \leq 0.05$.

\section{Leaf pigments contents}

The mean values of leaf pigments (chlorophyll and anthocyanin) contents are available in Figures 1a and $b$. There were significant effects in the interaction between $\mathrm{HA}$ addition treatments and foliar application times. The highest level of $(2.0 \mathrm{~g} / \mathrm{L})$ in the all-time applications significantly increased the total chlorophyll and anthocyanin contents in leaves, as compared with all unsprayed treatments. In the present study, the total chlorophyll and anthocyanin contents in Calendula plants treated with foliar HA for three and four application times increased at higher levels, while HAuntreated plants had lower total chlorophyll and anthocyanin contents in leaves.

\section{Gas exchange measurements}

$C_{i}$ and $g_{s}$ were higher in unsprayed plants compared to foliar application plants for all the HA foliar treatments (Figs. 2a, b, c and d). In HA foliar application Calendula plants, the values of $E$ (Fig. 2b) in decreased one, two- and four-times treatments, and increased in three times treatment. The value of $P_{n}$ (Fig. 2a) increased in 1.0 and $2.0 \mathrm{~g} / \mathrm{L}$ HA foliated plants with three times treatment, and increased in 1.0, 1.5, and 2.0 $\mathrm{g} / \mathrm{L}$ foliated plants with four times. Values of $g_{s}$ (Fig. 2c) and $C_{i}$ (Fig. 2d) were lower in different sprayed levels of HA plants treated with diverse HA foliar application times compared to those of unsprayed treatments. Figures (2c and d) pointed out that the values $g_{s}$ and $C_{i}$ were decrease with increase foliar application times and foliar levels of HA. The lowest value of $g_{s}$ and $C_{i}$ were recorded through the HA foliar three and four times treatments under all foliar application levels. 


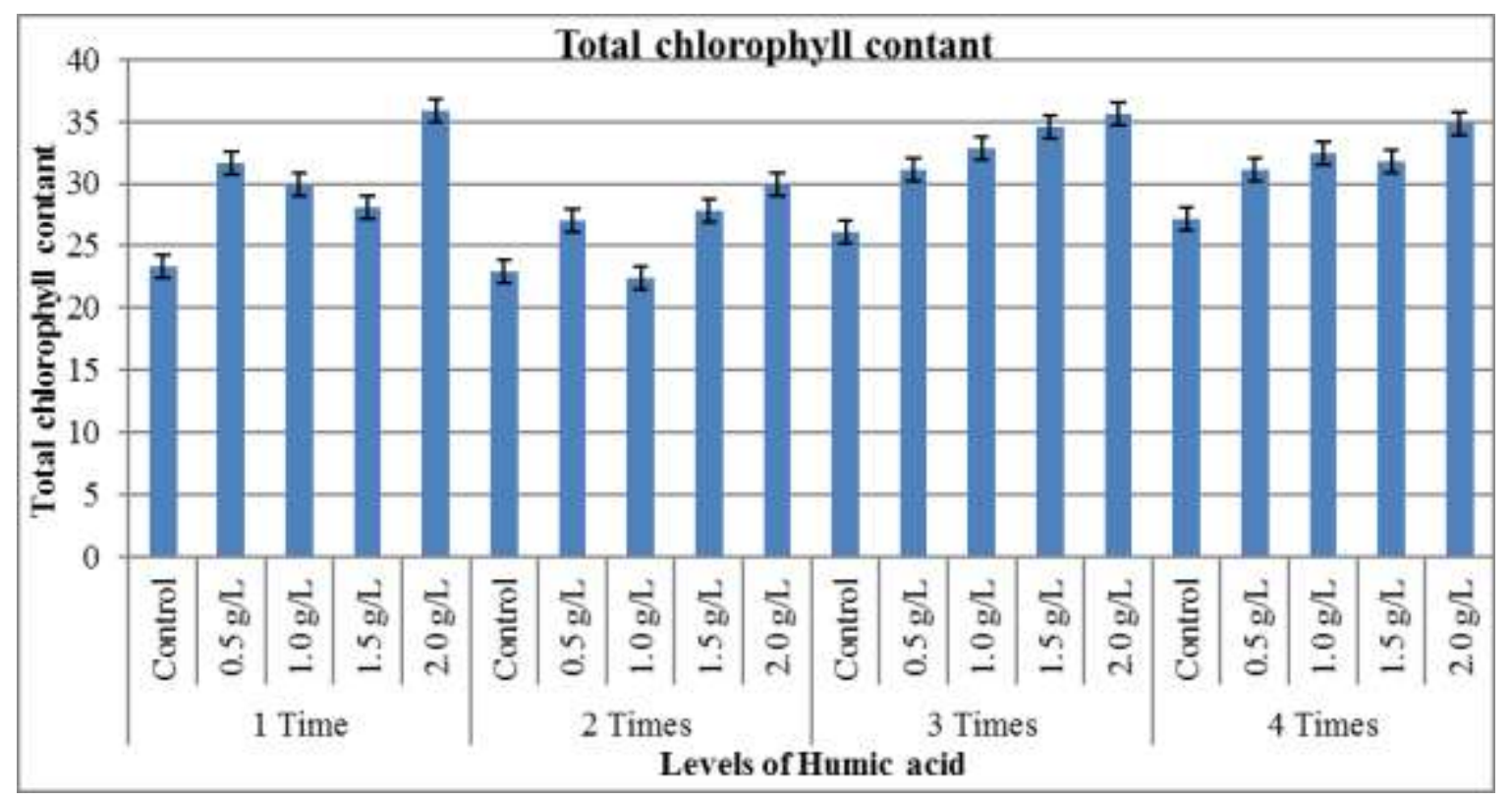

Fig. 1a. Effects of the interaction of the humic acid treatments (times and levels of foliar application) on total chlorophyll content of Calendula plants

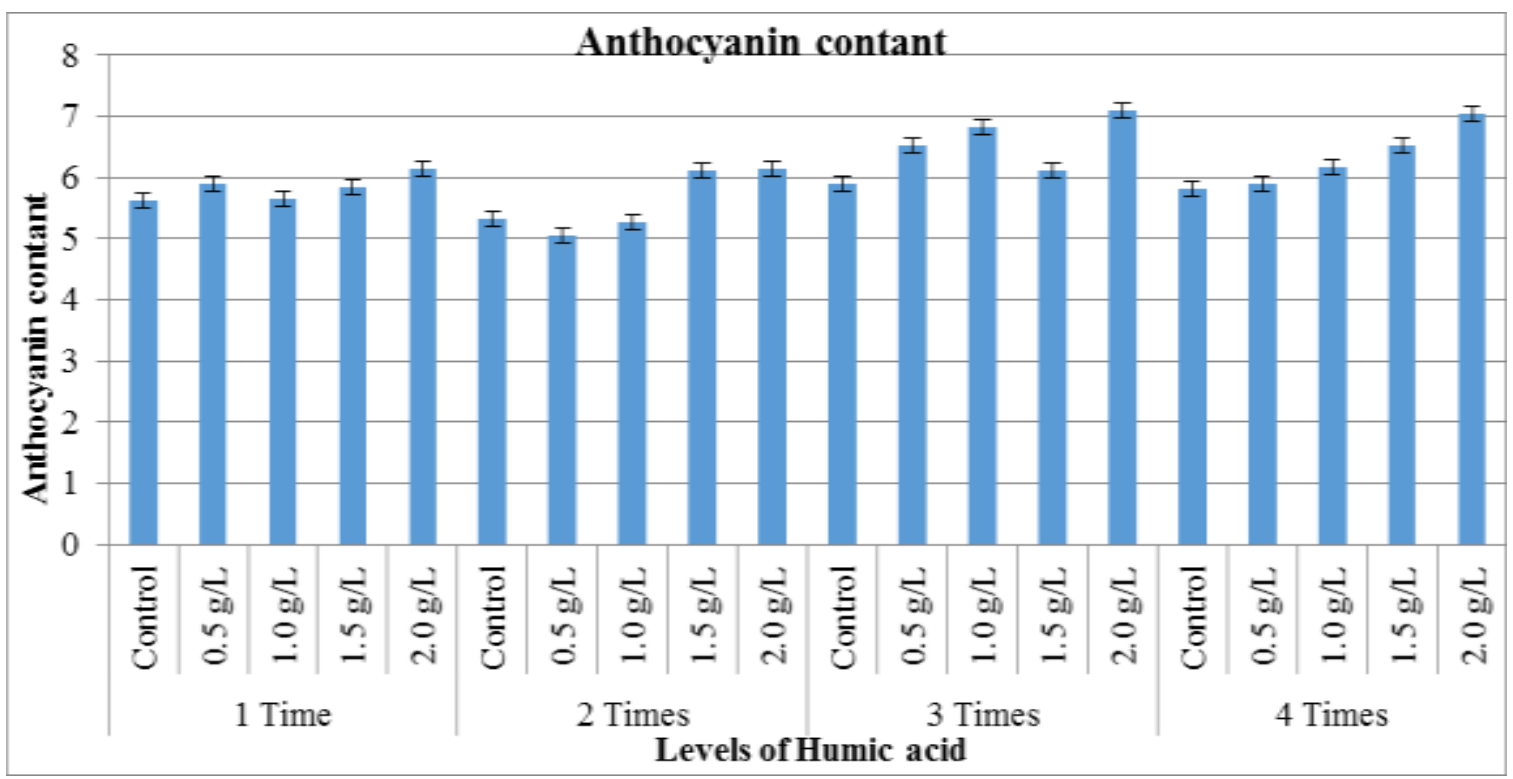

Fig. 1b. Effects of the interaction of the humic acid treatments (times and levels of foliar application) on anthocyanin content of Calendula plants 


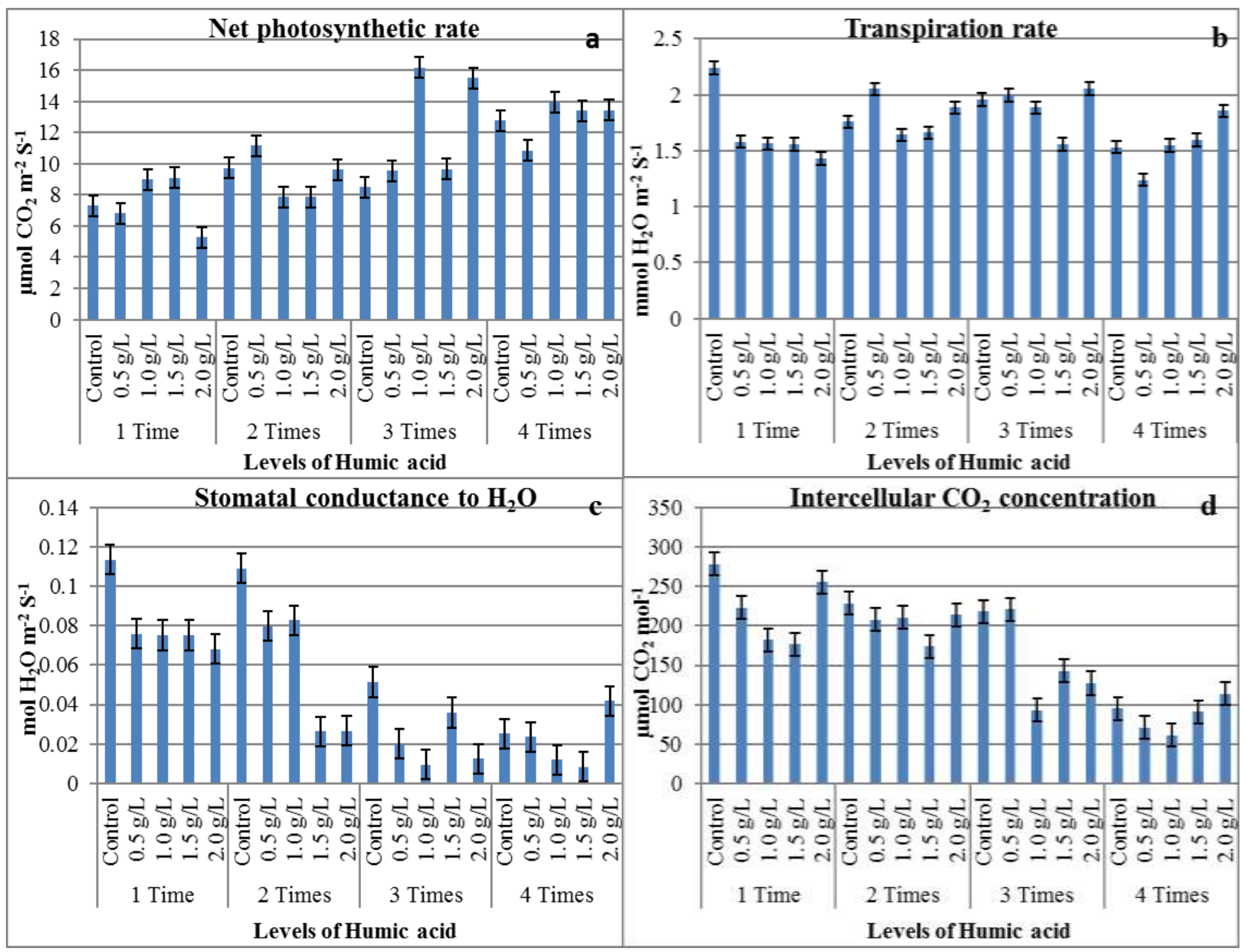

Fig. 2. Effects of the interaction of the humic acid treatments (times and levels of foliar application) on net photosynthesis rate (Pn) (a), transpiration rate (E) (b), stomatal conductance to $\mathrm{H2O}$ (gs) (c), and intercellular $\mathrm{CO} 2$ concentration $(\mathrm{Ci})(\mathrm{d})$ of Calendula plants

\section{Leaf water potential}

The leaf water potential $\left(\Psi_{\mathrm{wP}}\right)$ is related to plant cells content and markedly affected, once plant is exposed to stress. In the present study HA also showed positive influence on water relation of Calendula. Leaf water potential significantly increased with increasing HA foliar application times under foliar levels of
Calendula plants (Fig. 3). The highest value (positive influence) of water potential was obtained at $2.0 \mathrm{~g} / \mathrm{L} \mathrm{HA}$ with three foliar application times $(-0.223 \mathrm{Mpa})$, while the lowest value (negative influence) was obtained at $1.0 \mathrm{~g} / \mathrm{L}$ HA with two foliar application times $(-3.336$ Mpa). 


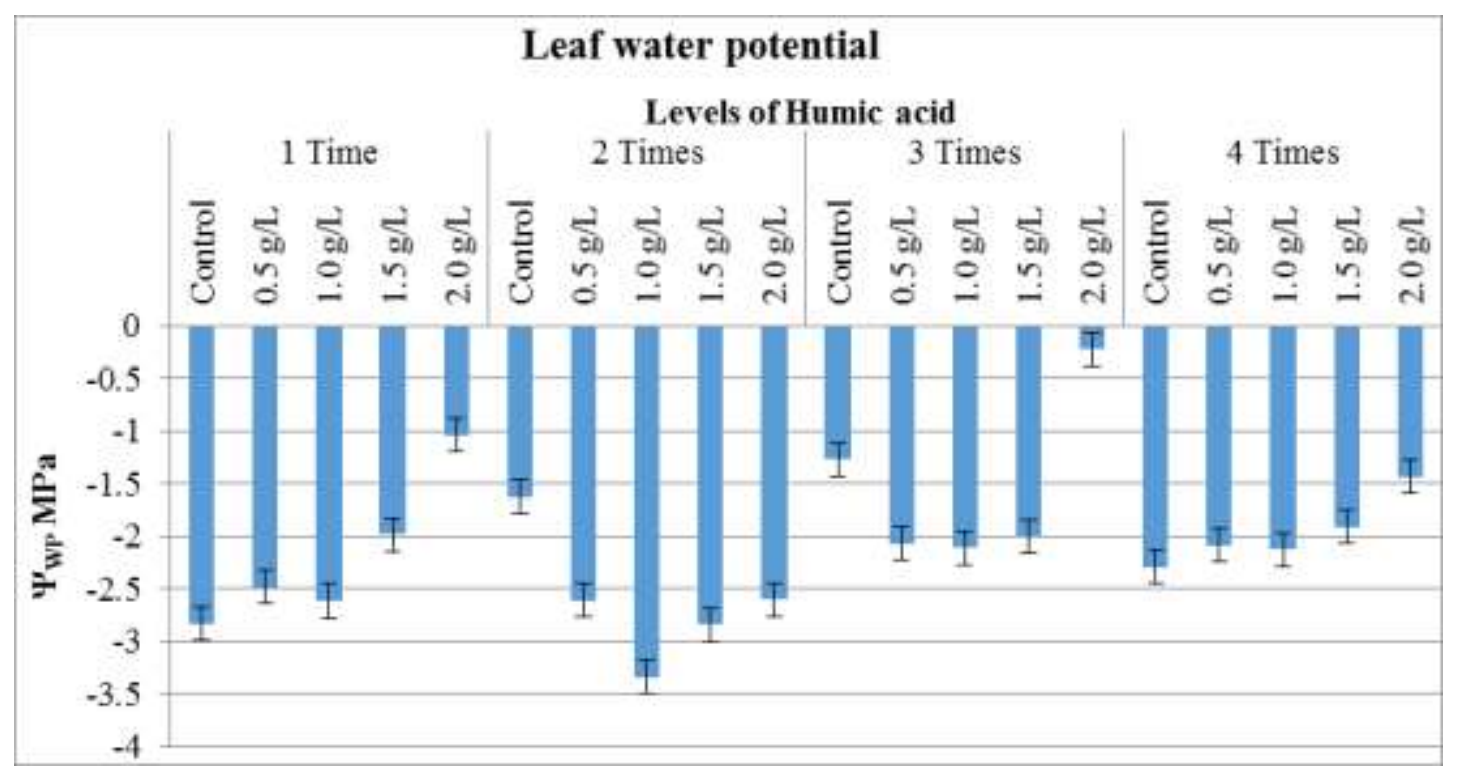

Fig. 3. Effects of the interaction of the humic acid treatments (times and levels of foliar application) on leaf water potential of Calendula plants

\section{DISCUSSION}

Plant fertilization is needed for improving vegetative growth and flower quality. Foliar application of HA had a positive effect on the vegetative and flowering growth parameters of Calendula, meanwhile spraying plants with HA cased augment in height plants, number of branches, no. of leaves, leaf area, shoot dry mass, root length plant ${ }^{-1}$ and leaf total chlorophyll and anthocyanin contents as compared to unsprayed plants. This influence may be owing to the effects of HA materials on the vegetative growth of plants are documented through physiological, morphological, and biochemical effects (Hasan, 2019), In this study, HA at high concentration $(2.0 \mathrm{~g} / \mathrm{L})$ with three foliar application times increased the number of leaves and number of branches plant ${ }^{-1}$ which could be owing to the positive mineral effect and also hormone-like activity of HA on vegetative growth parameters (Nikbakht et al., 2008; Kamari Shahmaleki et al., 2010). Morard et al. (2011) and Elkhateeb et al. (2011) illustrated that the usage of inoculate HA significantly augmented leaf area plant ${ }^{-1}$ in Acacia saligna as compared to the control. On the other hand, the positive influence of HA's on shoot dry mass might be aptitude to elements absorption as of its result on plant dry biomass which approves (AbdelMawgoud et al., 2007; Mohammadipour et al., 2012). Fan et al. (2015) found that Chrysanthemum flowers dry weight increased with foliar HA application.

Also (Zhang and Ervin, 2004) indicated that the attendance of iron element in the HAs or their colloidal nature have a real effect on the growth of diverse microorganisms which may excrete a variety of antibiotics, vitamins, and growth substances and these can active plant growth. Karakurt and Padem (2009) reported that foliar application of Potassium-humate to the plants led to improve and increase growth characters of plants.

Moreover to the influence of HA on flowering growth traits showed augmented in the number of flowers on Calendula plant, diameter of flower, flower dry mass plant ${ }^{-1}$, and diminish days required to flower bud initiation as compared to unsprayed treatment. This influence may be attributed to (Azooz, 2009; Hasan, 2019) who indicated that HA increase chlorophyll density, photosynthesis, and plant root breathing which influenced main plant growth. This result is in agreement with Ahmad et al. (2013) who reported that the HA improve vegetative and flowering growth. Used HA on pelargonium plant led to augmented flowers number and leaf area unit with elements absorption and its hormone-like properties which are in close agree with the results obtained (Morard et al., 2011). Savvas and Gizas (2002) and Ehsan et al. (2012) mention that HA had helpful influence on flowers number and yield which might be owing to the positive impact of HA compounds on nutrients absorption, and this eventually augments the number of flowers. Humic acid material has auxin-like activity; enhanced element uptakes which may be accountable for the foliar applications of HA caused earlier flowering and higher produce in pot marigold plant (Ricardo et al., 1993). Evans and Li (2003) illustrated that foliar HA applications by concentrations from 2500 to $5000 \mathrm{mg} \mathrm{L}^{-1}$ had helpful effects on the increase of leaf number, length of roots, stem length, and flower number in Calendula. Nikbakht 
et al. (2008) mentioned that HA at $500 \mathrm{mgl}^{-1}$ produced healthier plant growth and improved flower and quality yield of gerbera plant. Singh et al. (2008) mentioned that the usage of bio-fertilizers improved growth and flower yield indexes in Calendula. Nikbakht et al. (2008) found that high level of HA treatment produced a 52\% flowers yield increase Gerbera Jamesonii L. cv. 'Malibu' flowers, this results agree with the results of our investigation. These influences have been also confirmed in our investigation on Calendula officinalis.

The total chlorophyll and anthocyanin contents of Calendula had shown significant augment with increase the application times of HA under increase the levels of HA (Figs. 1a and b). Robert and Robyn (1982) found that the increase in total chlorophyll content may be owing to the rate of quenching of chlorophyll fluorescence which was evidently increased in the HA sunflower leaves and the stable state rate of quenching was a better than in un-treatment leaves. The results pointed out the morphological indices the total chlorophyll and anthocyanin contents, the chlorophyll fluorescence, and the chloroplast ultra-structure of Chrysanthemum hortorum Hort. healthier clearly after foliar HA application compared by those of the unsprayed (Fan et al., 2014). The coal-Humic fertilizers helped the biochemical processes in plants as leaf pigments (chlorophyll and anthocyanin contents), photosynthesis, and respiration this influence may be attributed to (Abolina and Tashkhadzhaev, 1968).

Man-hong et al. (2020) found that HA decreased the $C_{i}$ and $E$ and improved the $P_{n}$ and $g_{s}$ with different water deficits compared with the control. (Fan et al., 2014) mention that the results morphological indices the net photosynthesis rate and stomatal conductance of Chrysanthemum hortorum Hort. improved clearly after foliar HA application compared with those of the unsprayed. Zulfiqar et al. (2019) reported that the gas exchange (photosynthetic rate, transpiration rate and stomatal conductance) results confirmed that foliar HA treatments were able to improve the Gazania rigens $\mathrm{L}$. parameters. The leaf water potential calculated for each foliar HA application showed higher values in the 600 $\mathrm{mgL}^{-1}$ highest treatment (Zulfiqar et al., 2019). This is in agree with preceding investigation that HA might improve the yield of crop resistance to water potential, and enhance the elements uptake and application, and thus increase yield of crop underneath unfavorable water of soil conditions (Ali et al., 2015). The gas exchange measurements confirmed that HA applications were able to improve the Calendula parameters.

Additional studies must be carried out for foliar HA applications and, in specific, higher levels must be careful, because the results showed that the saturation of the response was not touched at the higher level.
Though, a cost-benefit evaluation must be also taken into consideration in order to identify which treatment and level combination gives the highest wage.

\section{CONCLUSIONS}

According to the results attained in this investigation, the influence of humic acid on growth parameters of Calendula plants was positive and this organic fertilizer produced the highest vegetative growth parameters and had active role in the Calendula flowers parameters as compared with control.

Among HA foliar treatments three foliar application times of HA along with 1.5 and $2.0 \mathrm{~g} / \mathrm{L}$ surpassed all other foliar treatments for most of vegetative, flowering growth parameters and physiological indices of the Calendula production and showed to be effective for enhancing yield and quality of Calendula plants.

Funding statements: The author did not receive any external funding for this study.

Conflicts of interest: The author declares that there are no conflicts of interest related to the publication of this study.

\section{REFERENCES}

Abdel-Mawgoud, A.M.R., N. H. M. El-Greadly, Y. I. Helmy and S. M. Singer. 2007. Responses of Tomato plants to different rates of Humic-based fertilizer and NPK fertilization. Journal of Applied Sciences Research. 3: 169-174.

Abolina, B. I. and A. T. Tashkhadzhaev. 1968. Effects of coalhumic fertilizers on the activity of physiological processes in plants and in the yield of otatoes in uzbekistan. Guminovye Udabr. Guminovye Udabr. 1: 118-126.

Ahmad, I., R. U. Saquib, M. Qasim, M. Saleem, A. S. Khan and M. Yaseen. 2013. Humic acid and cultivar effects on growth, yield, vase life, and corm characteristics of gladiolus. Chilean Journal of Agricultural Research. 73(4): 339-344.

Ali, S., S. A. Bharwana, M. Rizwan, M. Farid, S. Kanwal, Q. Ali, M. Ibrahim, R. A. Gill and M. D. Khan. 2015. Fulvic acid mediates chromium $(\mathrm{Cr})$ tolerance in wheat (Triticum aestivum L.) through lowering of $\mathrm{Cr}$ uptake and improved antioxidant defense system. J. Environ. Sci. Pollut. R. 22: 10601.

Arancon, N. Q., S. Lee, C. A. Edwards and R. Atiyeh. 2003. Effect of humic acids derived from cattle, food and paper waste vermicompost on growth of green house plants. Pedobiologia. 47:741-744.

Azooz, M. M. 2009. Foliar application with riboflavin (vitamin B2) enhancing the resistance of Hibiscus sabdarffa, L. (Deep Red Variety) to salinity stress. Journal of Biology science. 9(2): 109-118.

Baldotto, M. A. and L. E. B. Baldotto. 2013. Gladiolus development in response to bulb treatment with different concentrations of humic acids. Revista Ceres. 60:138-142. 
Bhardwaj, K. K. and A. C. Gaur. 1970. The effect of Humic acid on the growth and efficiency of $\mathrm{N}$ fixation of Azotobacter Ohroococum. Folia. 15:367.

Bryan, H. H. 1976. Response of tomatoes to seed and seedling applications of humates and alpha-keto acids. Proc. Fla. State Hort. Soc. 89(1): 87-90.

Chen, Y. and T. Aviad. 1990. Effects of humic substance on plant growth. Humic substances in soil and crop sciences: Selected readings. Soil Science Society of America Journal, pp. 161-186.

De Kreij, C. and H. Başar. 1995. Effect of humic substances in nutrient film technique on nutrient uptake. Journal of Plant Nutrition. 18(4): 793-802.

Ehsan, M., A. Golchin, J. Mohammadi, N. Negahdar and M. Zarchini. 2012. Improvement fresh weight and aerial part yield of Marigold (Calendula officinalis L.) by humic acid. Annals of Biological Research. 3(11): 5178-5180.

El-Khateeb, A., A. S. El-Leithy and B. A. Aljemaa. 2011. Effect of mycorrhizal fungi inoculation and humic acid on vegetative growth and chemical composition of Acacia saligna Labill. seedlings under different Irrigation Intervals. Journal of Horticultural Science \& Ornamental Plants. 3(3): 283-289.

Evans, M. R. and G. Li. 2003. Effect of humic acids on growth of annual ornamental seedling plugs. HortTechnology. 13: 661-665.

Fan, H. M., X. W. Wang and X. Sun. 2014. Effects of humic acid derived from sediments on growth, photosynthesis and chloroplast ultrastructure in chrysanthemum. Scientia Horticulturae. 177: 118-123.

Fan, H., T. Li, X. Sun and C. Zheng. 2015. Effects of humic acid derived from sediments on the postharvest vase life extension in cut chrysanthemum flowers. Postharvest Biology and Technology. 101: 82-87

Golestani, M., A. Dolatkhahi and F. Kazemi. 2013. Effect of planting dates on flowering period of Calendula officinalis, Bellis perennis and Viola sp. Advanced Crop Science. 3(8): 563-567.

Hartwigsen, J. A. and M. R. Evans. 2000. Humic acid seed and substrate treatments promote seedling root development. Horticultural Science. 35:1231-1233.

Hasan, A. M. 2019. Effect of foliar application of humic acid and benzyladenine on growth and flowering of pot marigold (Calendula officinalis L.). Journal of University of Duhok., Agri. and Vet. Sciences. 22(1): 69-77.

Kamari Shahmaleki, S., Q. Peyvast and J. Olfati. 2010. Journal of Horticultural Sciences. 24(2): 149-153.

Karakurt, Y., H. Unlu and H. Padem. 2009. The influence of foliar and soil fertilization of humic acid on yield and quality of pepper. Acta Agriculture. Scandinavica. 59(3): 233-237.

Kononova, M. M. 1966. Soil organic matter its nature and role in soil formation and fertility. New York, Oxford. 544 pp.

Lawson, G. J. and D. Stewart. 1989. Humic substances in soil, sediment and water. York: Publisher MacCarthy Wiley Inter Science New.
Mackowiak, C. L., P. R. Grossl and B. G. Bugbee. 2001. Beneficial effects of humic acid on micronutrient availability to Wheat. Soil Science Society of America Journal. 65(6): 1744-50.

Man-hong, Y., L. Zhang, X. Sheng-tao, N. B. McLaughlin and L. Jing-hui. 2020. Effect of water soluble humic acid applied to potato foliage on plant growth, photosynthesis characteristics and fresh tuber yield under different water deficits. Scientific Reports. 10:7854.

Memon, S. A. and K. Khetran. 2014. Effect of humic acid and calcium chloride on the growth and flower production of Snapdragon (Antirrhinum majus). International Journal of Agricultural Technology. 10(6): 1549-1561.

Mohammadipour, E., A. Golchin, J. Mohammadi, N. Negahdar and M. Zarchini. 2012. Improvement Fresh Weight and Aerial Part Yield of Marigold (Calendula officinalis L.) by Humic Acid. Annals of Biological Research, 3(11): 5178-5180.

Morard, P., B. Eyheraguibel, M. Morad and J. Silvestre. 2011. Direct effects of humic-like substance on growth, water, and mineral nutrition of various. J. Plant Nutr. 34(1): 4659.

Nikbakht, A., M. Kafi, M. Babalar, Y. Xia, A. Luo and N. Etemadi. 2008. Effect of humic acid on plant growth, nutrient uptake, and postharvest life of Gerbera. J. Plant. Nutr. 31(12): 2155-2167.

Nisar, A. and S. Mir. 1989. Lignitic coal utilization in the form of Humic acid as fertilizer and soil conditioner. Science, Technology and Development. 8: 23-26.

Pan, R. C. and Y. D. Dong. 1995. Plant Physiology Third edition. Beijing, China: High Education Press.

Ricardo, R., P. Raymond, Poincelot and P. B. Graeme. 1993. The use of a commercial organic bio-stimulant for improved production of marigold cultivars. Journal of Home and Consumer Horticulture. 1:83-93.

Rigane, G., S. Ben Younes, H. Ghazghazi and R. Ben Salem. 2013. Investigation into the biological activities and chemical composition of Calendula officinalis L. growing in Tunisia. International Food Research Journal. 20(6): 3001-3007.

Robert, M. S. and N. Robyn. 1982. Salt tolerance in crop plants monitored by chlorophyll fluorescence In vivo. Plant Physiol. 70: 1049-1054.

Salman, S. R., S. D. Abou-Hussein, A. M. P. Abdel-Mawgoud and M. A. El-Nemr. 2005. Fruit yield and quality of watermelon as affected by hybridsand humic acid application. Journal of Applied Sciences Research. 1: 5158.

Samadimatin, A. and A. Hani. 2017. Effect of ethanol and humic acid foliar spraying on morphological traits, photosynthetic pigments and quality and quantity of essential oil content of Dracocephalum moldavica L. Iranian Journal of Plant Physiology. 8(1): 2299-2306.

Savvas, D. and G. Gizas. 2002. Response of hydroponically grown gerbera to nutrient solution recycling and different nutrient cation ratios Scientia. Hort. 96(1): 267-280. 
Sharif, M., R. A. Khattak and M. S. Sarir. 2003. Residual effect of Humic acid and chemical fertilizerson maize yield and nutrient accumulation. Sarhad Journal of Agriculture. 19:543-549.

Sibanda, H. M. and S. D. Young. 1989. Competitive adsorption of humus acids and $\mathrm{P}$ on goethite, gibbsite and two trop. soils. Journal of Soil Science. 37:197-204.

Singh, Y. P., R. Dwivedi and S. V. Dwivedi. 2008. Effect of bio-fertilizer and graded dose of nitrogen on growth and flower yield of calendula (Calendula officinalis L.). Plant Archies. 8(2): 957-958.

Steel, R. G. D., J. H. Torrie and D. A. Dickey. 1997. Principles and Procedures of Statistics, A Biochemical
Approach, $3^{\text {rd }}$ ed. McGraw Hill Book Co. Inc., New York, USA. 666 p.

Vaughan and Donald 1976. Some effect of HA on cation uptake by prenchyme tissue. Soil Biology and Biochemistry. 3: 51-53.

Zhang, X. and E. H. Ervin. 2004. Cytokinin-containing seaweed and humic acid extracts associated with creeping bent grass leaf cytokinins and drought resistance. Crop Science. 44: 1737-1745.

Zulfiqar, F., A. Younis, Z. Abideen, A. Francini and A. Ferrante. 2019. Bio-regulators can improve biomass production, photosynthetic efficiency, and ornamental quality of Gazania rigens L. Agronomy. 9(773): 1-13.

\title{
الملخص العربي \\ تأثير مستويات حامض الهيوميك المطبقة في أوقات مختلفة على تحسين نمو نبات الكلانديولا \\ (Calendula officinalis L.)
}

\author{
ياسر إسماعيل النشار \\ حسنت ارتفاع النبات، عدد الأوراق، مساحة الورقة، الوزن \\ الخضري الجاف للنبات، وكذللك عدد الأزهار، قطر الزهرة \\ والوزن الجافة للأزهار ، وخفضت الوقت اللازم للأزهار • وكان \\ تأثير التطبيق الورقي لحامض الهيوميك للجرعة (, ( و •, r \\ جم / لنر) لنالث مرات واضح على نمو وتطور النباتات. \\ ولذلك فأن أستخدام حامض الهيوميك قد حسن نمو نبات \\ الكلانديولا (النمو الخضري والزهري)، وتحسين محتوى صبغة \\ الأوراق وقياسات التمثيل الضوئي، ويمثل فرصة لتحسين نمو \\ وانتاج نباتات الزينة.

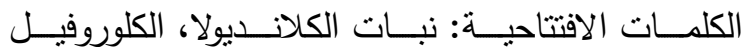 \\ والانثوثيانين، تبادل الغازات، الأجهاد المائي للأوراق، تاريخ

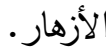 \\ الكلانديولا هو نبات حولي شتوي ينتمي إلى عائلة \\ الأسنز ، ويستخدم كبساط للمناظر الطبيعية أو كنباتات زينة \\ في أصص. يمكن تحسين الاستدامة الاقتصادية والبيئية

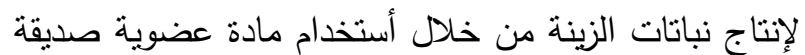 \\ للبيئة منل حامض الهيوميك. تم رش شتلات الكلانديولا \\ بواسطة حامض الهيوميك الورقي العضوي (صفر، 0, ،

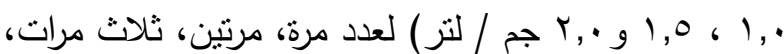 \\ أربع مرات كل 10 يوما بعد تقريد الثتلات. ونفس الحجم من \\ الماء المقطر للمعاملة الكنترول (رش ماء فقط)، تم ملاحظة \\ تأثثر حامض الهيوميك على النمو، ومحتوي الأوراق من

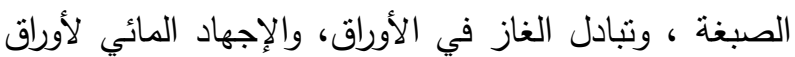 \\ نبات الكلانديولا. أظهرت النتائج أن النباتات المعاملة \\ بالتركيزات المختلفة من الإضافة الورقية لحامض هيوميك
}

